\title{
Autism spectrum disorder: advances in evidence-based practice
}

\author{
Evdokia Anagnostou MD, Lonnie Zwaigenbaum MD, Peter Szatmari MD, Eric Fombonne MD, \\ Bridget A. Fernandez MD, Marc Woodbury-Smith MD PhD, Jessica Brian PhD, Susan Bryson PhD, \\ Isabel M. Smith PhD, Irene Drmic PhD, Janet A. Buchanan PhD, Wendy Roberts MD, Stephen W. Scherer PhD
}

A utism spectrum disorder (ASD) encompasses wide variation in symptom severity and functional impact. The core features of ASD include impairments in social communication, repetitive behaviours and restricted interests. Not all people with ASD identify their challenges as a disorder. Autism spectrum disorder affects more than $1 \%$ of the population, ${ }^{1}$ and a dramatic increase in its recognition is creating huge demands on health care systems for timely and accurate diagnosis. Health care professionals in many capacities encounter people and their families coping with ASD, and optimal care depends on a large network of providers, given the breadth of the associated medical issues.

In this review, we outline the current understanding of ASD and suggest best practices for primary care and specialized clinics based on evidence from randomized controlled trials (RCTs) or systematic reviews, if available (Box 1). Although collaboration with educational and social services is necessary, the focus of our review is on medical concerns. We use a fictional case to illustrate how the process may be applied (Box 2). Additional resources for physicians are presented in Box 3.

\section{How common is autism?}

The Autism and Developmental Disabilities Monitoring Network of the US Centers for Disease Control has surveyed ASD among eightyear-olds from up to 14 US centres every two

\section{Box 1: Preparing this review}

We each contributed to the review according to our specialty. We selected the most informative recent peer-reviewed literature (using tools such as MEDLINE, Embase and PubMed). The recommendations presented here are based on evidence from randomized controlled trials or systematic reviews, if available. If there are gaps in such evidence, recommendations are based on our expert opinion. years since 2000. The most recent analysis, which pertains to the 2008 surveillance year, ${ }^{1}$ estimates the overall prevalence to be 1 in 88 children - almost double the prevalence reported in the original cohort. These data cannot distinguish between an increase caused by changes in ascertainment and a true increase in prevalence. Global prevalence, as reported in a comprehensive survey of epidemiological reports from 1966 to $2011,{ }^{2}$ suggests that autism is still under-recognized, particularly in developing countries. In Canada, a population prevalence of $1 \%$ implies that about 67000 children, aged 320 years have ASD. Boys with ASD outnumber girls by as much as $4: 1$, but the underlying reasons for this difference remain elusive. ${ }^{3}$

\section{What causes autism?}

The causes of ASD are now thought to be multifactorial: genetic, epigenetic and nongenetic factors acting in combination through various paths. Although ASD is highly genetic and can be familial or inherited, most of the genomic variation recognized to date has occurred de novo in affected individuals; however, expanded family studies are likely to reveal more subtle inherited variants. Two recent large and overlapping studies involving three-year-old children with an older sibling with ASD found recurrence in families of $19 \%{ }^{4}$ and $27 \% .^{3}$ Expanded diagnostic criteria likely contribute to some of the apparent
Competing interests: See end of article.

This article has been peer reviewed.

Correspondence to: Stephen Scherer, stephen.scherer@sickkids.ca Evdokia Anagnostou, eanagnostou@hollandbloor view.ca

CMAJ 2014. DOI:10.1503 /cmaj.121756

\section{KEY POINTS}

- Autism is heterogeneous in cause and presentation; the spectrum of disorders is recognized in DSM-5 as a collective category called autism spectrum disorder (ASD).

- Autism spectrum disorder is much more common than previously thought (prevalence of about $1 \%$ ).

- Up to $20 \%$ of ASD cases are associated with genes, copy number variations and functional pathways; these findings direct focus to synaptogenesis and neural connectivity as common causal elements.

- Early detection through improved awareness, family studies or screening programs allows early and effective interventions. 
increase, although those with more intact language and cognitive skills (Asperger type) could be missed in such young cohorts.

\section{Box 2: Applying the advances in clinical practice (fictional case)}

When Brian was 18 months, his parents expressed concerns to their pediatrician about his social development. Brian was born at term by spontaneous vaginal delivery, with weight and height at the 50th percentile and head circumference at the 97th percentile. Ultrasonography of his head showed no obvious abnormality, and there were no neonatal complications. Brian achieved early developmental milestones as expected: social smiling at eight weeks, babbling by six months and walking by one year. His first words were at 18 months. His mother noted that Brian did not always look when his name was called, had minimal interest in other children and had difficulty disengaging from certain toys, such as model trains on a track. The results of an audiology assessment were normal. The pediatrician completed a Modified Checklist for Autism in Toddlers with the mother, and Brian was found to be "at risk for autism." She referred Brian to the local infant development-early intervention service. Given his relative macrocephaly, she ordered magnetic resonance imaging of his head; the results were normal.

At 24 months, Brian's family returned to the pediatrician with additional concerns, despite some gains made with early intervention services. Although his language development was progressing (three-word phrases and more than 100 words), his speech had become repetitive (i.e., repeating questions, reciting dialogue from videos and using scripts mixed with spontaneous language in his everyday life). He seemed interested in other children, but he never approached on his own and needed much encouragement to respond positively to another child's approach, tending to play near other children with minimal interaction. He could stay for hours with his face to the carpet watching model trains. He did not engage in pretend play (e.g., "feeding" stuffed animals). The pediatrician observed Brian playing repetitively with toys in the waiting room and interacting minimally with other children. Eye contact was present but variable. She attempted to draw Brian's attention to a toy on a shelf by engaging his gaze and shifting to look at the toy, but Brian failed to follow the look, even when she also pointed. Another noisy child led to significant stress for Brian, who tensed his body, flapped his arms and repeated a script from a favourite cartoon as he walked away.

The pediatrician diagnosed autism spectrum disorder (ASD), based on DSM-V criteria. She ordered a genomic microarray and referred the family to the local speech and language services and the autism early intervention program. The microarray report revealed a deletion of chromosome 1 p36.23-p36.32 and suggested referral to a clinical geneticist. The geneticist advised the pediatrician to order certain tests in advance, including cardiac and renal ultrasonography, thyroid testing and referral to an ophthalmologist. Renal ultrasonography showed a vesico-ureteral malformation, and the pediatrician referred Brian to urology. Thyroid studies suggested hypothyroidism, prompting referral to pediatric endocrinology.

Brian was seen by a clinical geneticist several months later. The deletion was not found in either parent and was presumed to be the cause of Brian's difficulties. The geneticist reassured parents about the low risk of recurrence in a sibling.

\section{Commentary}

This diagnosis of ASD was made by the child's pediatrician based on DSM criteria, and the child was referred to community services. Practices related to diagnosis vary among provinces and territories and between urban and rural settings. In some cases, each child with a possible ASD diagnosis can access a multidisciplinary team involving a primary care physician, psychologist, and perhaps a speech-language pathologist or occupational therapist or both. Elsewhere, an expert clinician (primary care physician or psychologist) provides the diagnosis and refers to other services. Any of these routes to care could be appropriate, based on the local system and resources, as long as an experienced clinician trained and competent in this area is responsible for guiding the process.
Current technologies can now elucidate the genetic cause in $10 \%-30 \%$ of people with ASD ${ }^{5,6}$ Copy number variations (CNVs) involve relatively large segments of DNA; rare CNVs or other deleterious smaller sequence alterations occur in about $10 \%$ of idiopathic cases of ASD; ${ }^{7}$ CNVs are now considered to cause ASD in some families. ${ }^{8}$ About another $10 \%$ of individuals with ASD have known genetic conditions, the most common being fragile $\mathrm{X}$ syndrome (1\%), tuberous sclerosis $(1 \%)$ or Rett syndrome $(0.5 \%){ }^{9}$

Heritability can be estimated by comparing concordance in monozygotic and dizygotic twins. Early heritability estimates for ASD were high, indicating that many more inherited genetic elements remain to be identified..$^{5}$ To that end, a new international initiative ${ }^{10}$ will sequence the genomes of 10000 people with ASD, aiming to delineate all of the genetic factors involved. Genetic studies have led to a surprising revelation that ASD involves hundreds of genes, the identification of neuronal synapses as targets for therapeutic interventions, and the adoption of clinical microarrays as the standard of care for ASD diagnosis. ${ }^{11,12}$

Incomplete concordance in monozygotic twins and an increase in ASD diagnoses suggest the interaction of environmental and genetic factors. In utero exposures (including medications such as valproic acid, thalidomide, misoprostol, terbutaline or antidepressants), environmental neurotoxicants (e.g., pesticides) and infections (e.g., congenital rubella) have been hypothesized to increase the risk of ASD. ${ }^{13}$ Even if confirmed through replication, these exposures would collectively explain only a small number of cases. Early hypotheses that suggested increased risk associated with vaccine exposure (i.e., through the measles-mumpsrubella vaccine or the preservative thimerosal) have been thoroughly disproved..$^{14,15}$

A recent methodologically rigorous study of ASD in twins found lower heritability (37\%) than previously thought, ${ }^{16}$ suggesting that environmental factors that are shared by twins more than by other siblings (e.g., in utero or perinatal effects) are more influential than heritable factors. (Such influences could, however, still act at the level of the gene.)

\section{How is ASD diagnosed?}

The diagnostic assessment of ASD allows a physician to determine if a child meets the accepted ASD criteria (usually per Diagnostic and Statistical Manual of Mental Disorders [DSM] criteria), identify comorbid medical or genetic syndromes or psychopathology, and identify the patient's treatment needs. Figure 1 
shows the typical paths to diagnosis, starting with concerns (including "red flags") raised by parents, teachers, childcare providers, early childhood educators, family physicians or pediatricians. Primary care providers then determine whether an assessment is needed for ASD or another developmental issue. A detailed developmental history is collected from the parents, and additional information is collected from teachers, early childhood educators and health professionals. It is essential for the primary care provider to spend time with the child engaged in structured play activities that assess social-emotional relatedness, the ability of the child to respond to and direct the attention of others, and his or her use of gestures, imitation, imagination and conversation. Multiple prospective and retrospective studies support the recommendations of comprehensive reviews and guidelines on diagnosis. ${ }^{18,19}$

Among people with ASD, $10 \%-25 \%$ have an associated "medical disorder" (e.g., a genetic syndrome such as fragile $\mathrm{X}$ syndrome or tuberous sclerosis, teratogenic exposure or neurologic disorder). ${ }^{20,21}$ Assessment of an individual with ASD should include obtaining thorough prenatal, perinatal, medical and family histories, and a physical examination to document growth parameters (particularly head circumference) and the presence or absence of dysmorphic features.

In 2009, the Canadian College of Medical Geneticists recommended genome-wide microarray analysis, rather than karyotyping, as a firstline laboratory investigation for individuals with $\mathrm{ASD}^{11}$ because of its enhanced detection of chromosome abnormalities at greater resolution and because a single microarray assay can reveal the equivalent of hundreds or thousands of targeted (probe) investigations. Positive findings may be helpful in a family's search for explanations, provide a genetic handle for predicting recurrence, alert physicians to certain risks associated with known genomic alterations, and may eventually allow targeted therapies. ${ }^{89}$

Other laboratory investigations should include testing for fragile $\mathrm{X}$ syndrome and sequencing of the PTEN gene for individuals with a head circumference of three or more standard deviations above the mean. Fragile X syndrome is relatively common and has specific health and reproductive implications for family members. Mutations in the PTEN gene, although rare, indicate a need for additional tumour surveillance for carriers. ${ }^{21}$ Mutations in the MECP2 gene are rare $(<2 \%)$ among females with ASD and have only been identified among those with comorbid intellectual disability. Mutation testing should be considered for females with ASD and intellectual disability, especially those with clear regression in development. ${ }^{22}$ Recognition of such X-linked mutations (sometimes leading to a Rett syndrome phenotype) is important for prognosis and the risk of recurrence, distinct from that associated with ASD.

Additional investigations such as electroencephalography or metabolic testing should be guided by clinical indicators. The routine use of neuroimaging remains controversial (because most children require sedation or general anesthetic), but we recommend neuroimaging at least for patients with "complex ASD" 23 (e.g., substantial dysmorphology, microcephaly and/or seizures). ${ }^{24}$ Table 1 summarizes the recommended clinical work-up for patients with ASD at our centres.

The key to accurate diagnosis is a clear understanding of skills and deficits in social communication and the extent to which these can be accounted for by the child's overall developmental level or by the presence of other disorders. The DSM-IV-TR (DSM text revision); criteria for autism have shown good sensitivity and specificity. ${ }^{28}$ Diagnostic difficulties can arise if the child is very young, has a mental age of less than 24 months or is severely intellectually disabled. Relatively intact language and intellectual abilities may lead to later identification. In such

\section{Box 3: Recommended resources}

\section{Information}

- Miles JH, McCathren RB, Stichter J, et al. MDGeneReviews: autism spectrum disorders. Seattle (WA): Univeristy of Washington; 2003. www.ncbi.nlm.nih.gov/books/NBK1442/

- The Cochrane Library. Cochrane review: autism spectrum disorder. www.thecochranelibrary.com/details/browseReviews/579405/Autistic-spectrum -disorder.html

- American Psychiatric Association. DSM-5 Development. www.dsm.org

- Centers for Disease Control. www.cdc.gov/ncbddd/autism

Research

- Simons Foundation Autism Research Initiative (SFARI): www.sfari.org

- Canadian Autism Intervention Research Network (CAIRN): www.cairn-site.com Support groups

- Autism Speaks Canada: www.autismspeaks.ca

- Autism Canada: www.autismcanada.org

- Provincial support groups

Tools and resources

- Autism Speaks (Canada), Autism Treatment Network: www.autismspeaks.ca/science/atn/

- Autism Treatment Network (ATN) Tool Kits: www.autismspeaks.ca/family -services/toolkits/ www.autismspeaks.org/science/resources-programs/autism-treatment-network /tools-you-can-use/sleep-tool-kit

- The National Autism Center's National Standards Project: www.national autismcenter.org/pdf/NAC Findings \& Conclusions.pdf

- Autism Diagnostic Observation Schedule-2 (2012): portal.wpspublish.com 


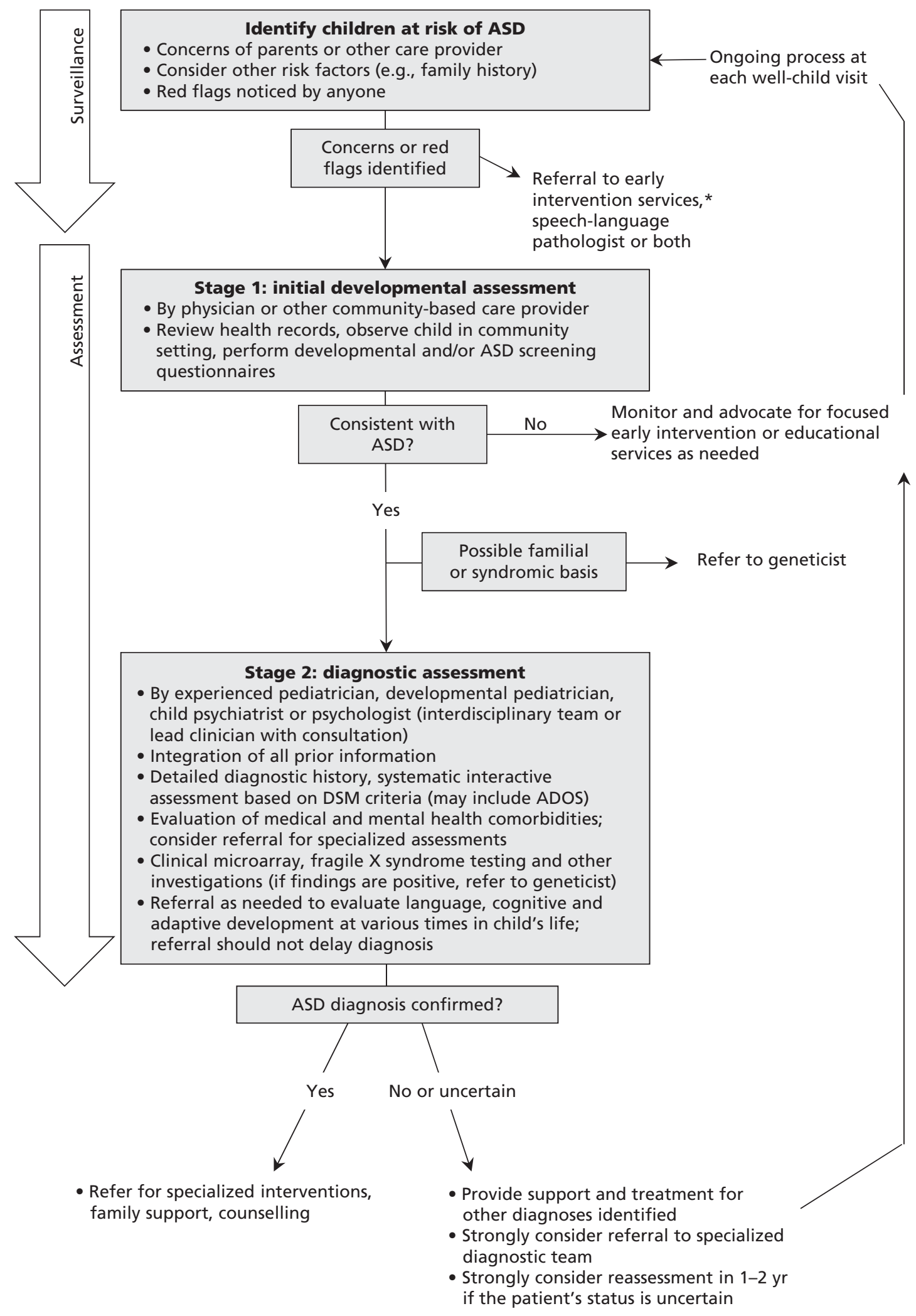

Figure 1: Pathways to diagnosis and treatment of autism spectrum disorder (ASD). Modelled after Levy and colleagues ${ }^{17}$ See Tables 1 and 2 for a list of red flags and other investigations, respectively. ${ }^{*} A t$ this stage, we refer to generic rather than ASD-specific services. The services may be called "Early Intervention," "Infant Development Programs," "Early Childhood Intervention Programs" or "Early Childhood Intervention Services" depending on the jurisdiction. Note: ADOS = Autism Diagnostic Observation Schedule, DSM = Diagnostic and Statistical Manual of Mental Disorders. 
cases, assessment of cognitive, social-emotional and communicative skills is invaluable.

The fifth edition of DSM (DSM-5) ${ }^{29}$ com- bines autistic disorder, Asperger disorder, childhood disintegrative disorder and pervasive developmental disorder not otherwise specified

Table 1: Recommended clinical work-up for autism spectrum disorder at the centres represented by the authors*

\begin{tabular}{|c|c|c|}
\hline Specialty & Indication for testing & Test \\
\hline \multirow[t]{4}{*}{ Genetics $9,12,22$} & All & $\begin{array}{l}\text { Genome-wide microarray, fragile } \mathrm{X} \\
\text { syndrome (FMR1 gene) }\end{array}$ \\
\hline & Head circumference $>+3$ SD & PTEN gene \\
\hline & Concerns about other conditions & $\begin{array}{l}\text { Tuberous sclerosis and others as } \\
\text { indicated }\end{array}$ \\
\hline & $\begin{array}{l}\text { Consider for females with } \\
\text { intellectual disability }\end{array}$ & MECP2 gene \\
\hline Neuroimaging 23,24 & $\begin{array}{l}\text { Complex ASD (clinical focal findings, } \\
\text { major dysmorphology, micro- or } \\
\text { extreme ( } \geq 4 \text { SD) macrocephaly, skin } \\
\text { lesions, seizures, focal EEG } \\
\text { abnormalities, motor regression) }\end{array}$ & $\begin{array}{l}\text { Brain magnetic resonance imaging } \\
\text { and/or spectroscopy } \dagger\end{array}$ \\
\hline Metabolic ${ }^{25}$ & $\begin{array}{l}\text { If clinically indicated (e.g., severe } \\
\text { intellectual disability and seizures, } \\
\text { developmental regression) }\end{array}$ & $\begin{array}{l}\text { Levels of venous blood gas; serum } \\
\text { ammonia; lactate, pyruvate and uric } \\
\text { acid; plasma amino acid; total, free and } \\
\text { acylcarnitine; urine organic acids, } \\
\text { mucopolysaccharides }\end{array}$ \\
\hline \multirow[t]{3}{*}{ General medical } & $\begin{array}{l}\text { Should be considered, especially for } \\
\text { developmental delay }\end{array}$ & $\begin{array}{l}\text { T4, TSH, complete blood count, ferritin } \\
\text { level }\end{array}$ \\
\hline & $\begin{array}{l}\text { If indicated (e.g., presence of lead } \\
\text { in the area where the family lives, } \\
\text { evidence of pica) }\end{array}$ & Lead level \\
\hline & If neuroleptic therapy is considered & $\begin{array}{l}\text { Fasting lipid profile, glucose, HbA1c, } \\
\text { electrocardiogram }\end{array}$ \\
\hline \multirow[t]{4}{*}{ Gastroenterology ${ }^{26}$} & $\begin{array}{l}\text { Pain after meals, night awakening } \\
\text { despite good sleep hygiene }\end{array}$ & $\begin{array}{l}\text { Rule out gastroesophageal reflux } \\
\text { disorder }\end{array}$ \\
\hline & High eosinophil count & Rule out eosinophilic esophagitis \\
\hline & $\begin{array}{l}\text { Bloating ( } 2 \text { or } 3 \text { times per wk for } \\
\text { more than } 2 \text { wk) }\end{array}$ & $\begin{array}{l}\text { Tissue transglutaminase levels (to rule } \\
\text { out celiac disorder) }\end{array}$ \\
\hline & Failure to thrive, weight loss & $\begin{array}{l}\text { Serum albumin, total protein, calcium, } \\
\text { vitamin D levels }\end{array}$ \\
\hline Neurology ${ }^{27}$ & $\begin{array}{l}\text { Suspected seizures, } \\
\text { documented regression }\end{array}$ & EEG (ideally sleep record) \\
\hline $\begin{array}{l}\text { Psychology or } \\
\text { psychiatry }\end{array}$ & $\begin{array}{l}\text { Mental health concerns } \\
\text { (e.g., anxiety, mood) }\end{array}$ & Comorbidity assessment \\
\hline \multirow[t]{2}{*}{ Psychology } & Need to establish mental age & $\begin{array}{l}\text { Cognitive and adaptive behaviour } \\
\text { assessment } \neq\end{array}$ \\
\hline & Learning concerns & $\begin{array}{l}\text { Cognitive, academic assessment (may } \\
\text { include evaluation of memory and } \\
\text { executive functioning) }\end{array}$ \\
\hline $\begin{array}{l}\text { Speech-language } \\
\text { pathology }\end{array}$ & Speech or language concerns & Speech-language assessment \\
\hline $\begin{array}{l}\text { Occupational and/or } \\
\text { physiotherapy }\end{array}$ & Motor or sensory concerns & Motor and/or sensory assessment \\
\hline Behaviour therapy & Behavioural concerns & Behavioural assessment \\
\hline \multicolumn{3}{|c|}{$\begin{array}{l}\text { Note: } \mathrm{EEG}=\text { electroencephalogram, HbA1c = glycated hemoglobin, } \mathrm{SD}=\text { standard deviation of the mean, } \mathrm{T} 4 \text { = tetraiodo- } \\
\text { thyronine, TSH = thyroid stimulating hormone. } \\
\text { *This list does not imply uniform practice. } \\
\text { tConsider adding magnetic resonance spectroscopy if there is regression or other clinical indicators of metabolic disease. } \\
\text { fMay not be needed at the time of diagnosis, but may be required later to ensure appropriate academic supports. }\end{array}$} \\
\hline
\end{tabular}


into a single omnibus category termed "ASD." This change reflects how the symptoms of these disorders represent a continuum from mild to severe rather than qualitatively distinct disorders. ${ }^{30}$ Public concerns over whether some higher-functioning individuals would be excluded from diagnosis, and thereby from benefits and supports, have not been supported by field trials that compared diagnoses made under DSM-IV and DSM-5. ${ }^{31}$

Various instruments may be used to facilitate structured observation or systematic history-taking. The Autism Diagnostic Observation Schedule $^{32}$ (specificity: 0.72-1.0; sensitivity: 0.720.98 , depending on age and severity ${ }^{33}$ ) and the Childhood Autism Rating Scale $2^{34}$ (sensitivity and specificity: each $0.82-0.95$, depending on age and severity for cut-off scores of $25.5^{35}$ ) have shown good reliability and validity. The Autism Diagnostic Interview-Revised ${ }^{36}$ may assist with obtaining a systematic patient history in specialized settings.

\section{Box 4: "Red flags" for autism in 12- to 18-month-old children ${ }^{40}$}

\section{Social communication}

- Reduced or atypical:

- eye gaze and shared or joint attention

sharing of emotion (less positive and more negative affect)

social or reciprocal smiling

social interest and shared enjoyment

orienting when his or her name is called

coordination of different modes of communication (e.g., eye gaze, facial expression, gesture, vocalization)

- Regression or loss of social-emotional connectedness

Language

- Delayed or atypical:

- babbling, particularly back-and-forth social babbling

- language comprehension and production (e.g., delayed or odd first words or unusually repetitive)

- unusual tone of voice (including crying)

- development of gestures (e.g., pointing, waving)

- Regression or loss of communication skills (including words)

Play

- Reduced or atypical:

- imitation of actions

functional and imaginative play

- Excessive or unusual manipulation or visual exploration of toys and other objects

- Repetitive actions with toys and other objects

Visual or other sensory and motor skills

- Atypical visual tracking, visual fixation (e.g., on lights)

- Under- or over-reaction to sounds or other forms of sensory stimulation

- Delayed fine and gross motor skills, atypical motor control (e.g., reduced muscle tone, reduced postural control for age)

- Repetitive motor behaviours, atypical posturing of limbs or digits

\section{How can we detect ASD early?}

Although more than $80 \%$ of children with ASD show clear behavioural signs by two years of age and a diagnosis can be made reliably this early, the average age at diagnosis is about four years. ${ }^{1}$ Earlier diagnosis would alleviate prolonged concerns of many families and expedite opportunities to benefit from specialized interventions, ${ }^{37,38}$ thereby reducing costs to families and society. ${ }^{39}$

Parental reports, analyses of home videos and, more recently, prospective studies of infants at increased risk of ASD have identified numerous red flags that distinguish toddlers with ASD from those with typical development or other developmental delays (Box 4). These signs were recently analyzed in a comprehensive literature review. ${ }^{41}$ Earlier in infancy, ASD may be reflected by atypical regulatory functions related to sleep, eating and emotions.

The most effective strategy for identifying children with early signs of ASD is still debated. The American Academy of Pediatrics and others have recommended universal screening at 18 and 24 months ${ }^{19}$ using standardized tools, whereas professional groups in Canada (e.g., Canadian Paediatric Society) tend to stress developmental surveillance, monitoring parents' concerns and observation of the child, with or without standardized tools. In parts of Canada, surveillance has been enhanced by the use of broadband developmental screens, such as the Nipissing District Developmental Screen, ${ }^{42}$ and other standardized approaches to documenting parental or clinician concerns. ${ }^{43}$ Infants at high risk, such as siblings of children with ASD, should be monitored closely by their family doctor or pediatrician, and there should be a lower threshold for further assessment within primary care or by specialists., ${ }^{416}$

Although a comprehensive review of screening for ASD is beyond the scope of this paper (for more detail, see Zwaigenbaum ${ }^{18}$ ), two measures - the Modified Checklist for Autism in Toddlers (M-CHAT) ${ }^{44}$ and the Infant-Toddler Checklist (ITC) ${ }^{45}$ — have good psychometric properties for screening and are recommended for use. The ITC has a sensitivity of $0.86-0.89$ and a specificity of $0.75-0.77$, with a positive predictive value (PPV) of $0.65-0.80 .45,46$ The MCHAT has a sensitivity of $0.77-0.97$ and a specificity of 0.38-0.99, with a PPV of 0.06-0.92.4,47-52 Both have been used to screen for ASD among children in community pediatricians' offices. ${ }^{44,53}$ The Social Communication Questionnaire, another screening tool, is appropriate for children above three years of age but not younger. ${ }^{44,55}$

Evidence prompts us to recommend a multistage process (Figure 1) in which a network of par- 
ents and community professionals contribute to the surveillance for ASD red flags, leading to referral for general developmental assessment by community physicians or other providers (e.g., speech language pathologists) (Table 1).

Community physicians play an essential role in identifying early signs of ASD and ensuring timely diagnosis. The greatest impact on outcome will come from careful attention to parents' concerns, observing early social and communication skills (e.g., interaction with parents and response to simple social games), immediate referral to available intervention services (e.g., infant development and/or speech-language services), and timely referrals for specialized assessments and interventions. ${ }^{40}$

\section{Which comorbidities characterize the autism spectrum?}

A number of medical and psychiatric comorbidities have been identified in patients with ASD. These comorbidities and the epidemiologic evidence supporting them are outlined in Appendix 1 (available at www.cmaj.ca/lookup/suppl/doi :10.1503/cmaj.121756/-/DC1). Children with ASD should be monitored for comorbid psychiatric disorders. Clinicians are becoming aware of the frequency of attention deficit hyperactivity disorder (ADHD), anxiety and mood disorders among these children; ${ }^{56,57}$ these conditions require identification and intervention as early as possible.

\section{What treatments and interventions are available, and are they effective?}

The goal of existing interventions is to facilitate the acquisition of skills, remove barriers to learning and improve functional skills and quality of life.

\section{Behavioural interventions}

Current best practices for preschool-aged children with ASD include a focus on improving language, cognitive and adaptive skills using applied behaviour analysis (ABA) techniques. ${ }^{58}$ Applied behaviour analysis refers to the application of empirically derived learning principles (i.e., the antecedent-behaviour-consequence contingency) to produce meaningful changes in behaviour. ${ }^{59}$ Such strategies are carefully engineered and implemented through a variety of approaches (e.g., discrete trial teaching to more naturalistic learning contexts) to teach skills and reduce problem behaviour. Applied behaviour analysis interventions can be provided in a variety of settings (e.g., home, specialized treatment centres, specialized or public schools) by a range of front-line therapists, ideally supervised by a psychologist or board-certified behaviour analyst who specializes in ASD.

A recent overview of meta-analyses ${ }^{60}$ found significantly enhanced outcomes associated with early intensive ABA-based treatment (typically for 2-3 yr) in four of five included meta-analyses (effect sizes 0.30 to $>1$ ); these findings have since been bolstered by a sixth meta-analysis. ${ }^{61}$ Gains appear to be greatest in verbal intelligence quotient (IQ) and language communication domains, ${ }^{62,63}$ for children with stronger pretreatment skills, if treatment is started earlier, ${ }^{64}$ and with greater intensity or duration of intervention. ${ }^{60-62,64}$ These gains achieved in various domains have been summarized in a recent Cochrane review. ${ }^{63}$ Although the overall quality of evidence is low, it is the best evidence available.

A recent study in Ontario reported predictors of outcome that account for some heterogeneity in treatment response. ${ }^{65} \mathrm{~A}$ recent $\mathrm{RCT}$ supported the efficacy of ABA-based intervention in toddlers by showing improvements in IQ, adaptive skills and diagnostic classification. ${ }^{37}$ Models vary, notably by how ABA principles are implemented, but everyday contexts (e.g., free play v. "tabletop") and activities based on the child's interests (v. therapist's agenda) have advantages, including greater generalization of learning. ${ }^{66}$ Questions remain about which forms and intensities of treatment are most effective for which children. Research on non-ABA-based treatments is sparse and shows limited efficacy ${ }^{67}$ Translation of evidence-based intervention into community practice is being evaluated, including in Canada. ${ }^{68}$ A key question is whether effective high-quality programs can be less costly and more sustainable; the findings from Nova Scotia are promising. ${ }^{38}$

Studies of the effectiveness of treatment programs for older children, youth and adults with ASD are scarce. Benefits have been reported for structured teaching practices, including ABAbased interventions, for a wide range of skill deficits and maladaptive behaviours..$^{58}$

\section{Biomedical interventions}

Despite advances in pharmacologic therapy for ASD over the past two decades, there are still no agents that address the core symptoms of the disorder. For individuals aged more than five years, large clinical trials have addressed the efficacy and safety of the major classes of medications used in the clinic. ${ }^{69,70,71} \mathrm{~A}$ few systematic reviews are available ${ }^{72-74}$ supporting the use of pharmacologic agents for associated symptoms. Table 2 
presents the level of evidence, adverse events and effect sizes for medications used to treat ASD-related behaviours and symptoms.

\section{Irritability and impulsive aggression}

Risperidone and aripiprazole, two atypical antipsychotic medications, are the only medications with an indication by the US Food and Drug Administration for ASD-related symptoms. Large RCTs have shown their efficacy for irritability. ${ }^{69,75}$ Cochrane systematic reviews have shown decreases in irritability using the Aberrant Behavior Checklist subscale with respiridone ${ }^{72}$ (8.09 points v. placebo) and aripiprazole (6.17 points v. placebo). ${ }^{73}$ Data from open-label and small RCTs suggest that other typical and atypical antipsychotics may be useful (Table 2).

\section{Hyperactivity and inattention}

Stimulants and atomoxetine may be effective for treating ADHD-like symptoms in patients with ASD, albeit with smaller effect and more adverse outcomes than in children with ADHD alone. ${ }^{71,77}$
Early data suggest a similar role for $\alpha-2$ adrenergic agonists, such as clonidine and guanfacine. ${ }^{79}$

\section{Repetitive behaviours}

Not all repetitive behaviours or restrictive interests in individuals with autism are interfering, and some behaviours can be shaped into functional skills. The effectiveness of selective serotonin reuptake inhibitors (SSRIs) for repetitive behaviours has been questioned: the largest clinical trial for ASD found no effect of citalopram, and its use was associated with adverse effects. ${ }^{70}$ Risperidone and aripiprazole significantly reduced repetitive behaviours in children with ASD, ${ }^{75,81}$ albeit with adverse outcomes that require caution. No clinical trials have investigated the use of SSRIs to treat anxiety and depression in patients with ASD.

\section{Sleep disturbances}

The use of melatonin among patients with ASD is associated with improved sleep parameters, minimal adverse outcomes and better daytime behaviour. A systematic review of the use of

Table 2: Medications used to treat autism spectrum disorder behaviours and symptoms

\begin{tabular}{|c|c|c|c|c|}
\hline Medication & $\begin{array}{l}\text { Target } \\
\text { behaviour }\end{array}$ & Evidence & On- or off-label & Adverse events* \\
\hline \multirow{2}{*}{$\begin{array}{l}\text { Atypical } \\
\text { antipsychotic } \\
\text { medications } \\
\text { (i.e., aripiprazole } \\
\text { risperidone) }\end{array}$} & $\begin{array}{l}\text { Irritability, } \\
\text { aggressiont }\end{array}$ & $\begin{array}{l}\text { Multiple, well-designed RTCs } \\
\text { supporting their use } \mathrm{u}^{69,75}\end{array}$ & FDA indication & \multirow{2}{*}{$\begin{array}{l}\text { Weight gain, metabolic syndrome } \\
\text { gastrointestinal effects, sedation, } \\
\text { akathisia, orthostatic hypo- } \\
\text { tension, tachycardia, extra- } \\
\text { pyramidal syndrome, neuroleptic } \\
\text { malignant syndrome (rare) }\end{array}$} \\
\hline & $\begin{array}{l}\text { Repetitive } \\
\text { behavioursł }\end{array}$ & $\begin{array}{l}\geq 2 \text { large RCTs support efficacy } \\
\text { (although not a primary outcome } \\
\text { measure) }\end{array}$ & Off-label & \\
\hline \multirow[t]{2}{*}{$\begin{array}{l}\text { Serotonin } \\
\text { reuptake } \\
\text { inhibitors }\end{array}$} & $\begin{array}{l}\text { Repetitive } \\
\text { behaviour§ }\end{array}$ & $\begin{array}{l}1 \text { unpublished and } 1 \text { published } \\
\text { large RCT (fluoxetine, citalopram): } \\
\text { no evidence for efficacy }{ }^{70}\end{array}$ & $\begin{array}{l}\text { Off-label, unless } \\
\text { comorbid obsessive- } \\
\text { compulsive disorder }\end{array}$ & \multirow{2}{*}{$\begin{array}{l}\text { Gastrointestinal effects, insomnia, } \\
\text { agitation, disinhibition, dry } \\
\text { mouth, headache, sexual } \\
\text { dysfunction }\end{array}$} \\
\hline & $\begin{array}{l}\text { Anxiety or } \\
\text { depression }\end{array}$ & $\begin{array}{l}\text { None in autism, but multiple } \\
\text { studies for pediatric anxiety } \\
\text { disorders and depression }\end{array}$ & $\begin{array}{l}\text { On-label for anxiety } \\
\text { disorders and } \\
\text { depression }\end{array}$ & \\
\hline Stimulants & $\begin{array}{l}\text { ADHD-like } \\
\text { symptomsף }\end{array}$ & $\begin{array}{l}>2 \text { RCTs (methylphenidate) } \\
\text { support its use }{ }^{76} ; \text { smaller studies } \\
\text { support longer-acting stimulants }\end{array}$ & On-label for ADHD & $\begin{array}{l}\text { Poor appetite, weight loss, } \\
\text { irritability, insomnia }\end{array}$ \\
\hline Atomoxetine & $\begin{array}{l}\text { ADHD-like } \\
\text { symptoms** }\end{array}$ & $\begin{array}{l}1 \text { large, } 1 \text { small RCT support } \\
\text { effectiveness }\end{array}$ & On-label for ADHD & $\begin{array}{l}\text { Gastrointestinal effects, insomnia, } \\
\text { orthostatic hypotension }\end{array}$ \\
\hline$\alpha$-agonists & $\begin{array}{l}\text { ADHD-like } \\
\text { symptoms }\end{array}$ & $\begin{array}{l}\text { Several small RCT and open label } \\
\text { studies in autism support efficacy }{ }^{79}\end{array}$ & $\begin{array}{l}\text { Clonidine: off-label; } \\
\text { guanfacine: FDA } \\
\text { indication for } \\
\text { ADHDt† }\end{array}$ & $\begin{array}{l}\text { Somnolence, hypotension, } \\
\text { bradycardia, dry mouth, } \\
\text { constipation, irritability }\end{array}$ \\
\hline Melatonin & $\begin{array}{l}\text { Initial } \\
\text { insomniał‡ }\end{array}$ & $\begin{array}{l}\text { Cochrane meta-analysis, positive } \\
\text { effect on initial insomnia } \\
\text { compared to placebo }\end{array}$ & Not regulated & $\begin{array}{l}\text { Headache, dizziness and nausea } \\
\text { (all rare outcomes) }\end{array}$ \\
\hline \multicolumn{5}{|c|}{ 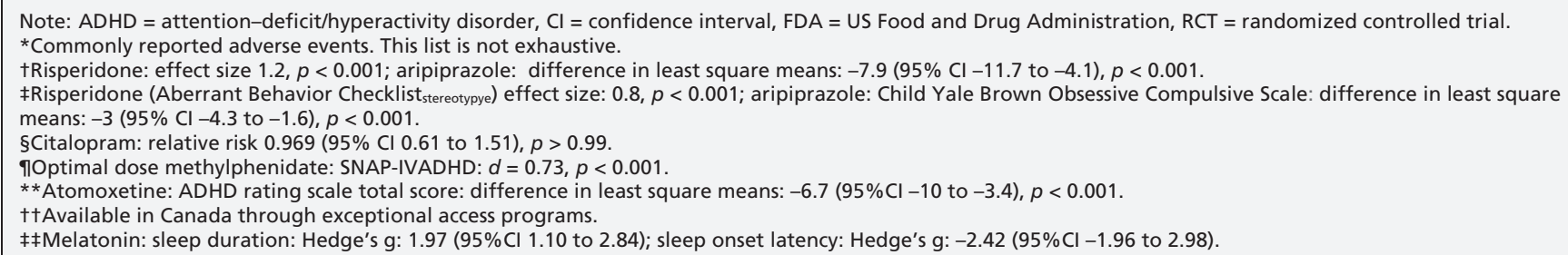 } \\
\hline
\end{tabular}


melatonin (v. placebo) in patients with $\mathrm{ASD}^{80}$ showed an improvement of 73 minutes in overall sleep and 66 minutes in sleep onset. However, research is needed to determine which sleep problems respond to sleep hygiene ${ }^{82}$ and behavioural interventions ${ }^{83}$ and which require medical intervention (see recent guideline ${ }^{74}$ ).

\section{Alternative medications}

Alternative or complementary approaches are often pursued by families, despite a lack of empirical support. Although some of these approaches have theoretical promise and deserve further research (e.g., omega-3 fatty acids, B complex vitamins, special diets), others are potentially harmful (e.g., chelation) or simply expensive and ineffective (e.g., secretin). ${ }^{84}$

\section{Outcomes}

Studies of outcomes among adults with ASD consistently show low to modest levels of independence and/or social inclusion among both higher- and lower-functioning individuals. ${ }^{85-87}$ Core phenotypic features and challenging behaviours persist, although some problems can improve over time. Some improved outcomes may be because of more inclusive and specialized educational programs. The level of verbal communication and IQ before five years of age are the strongest predictors of outcome.

\section{Future directions}

We have come to understand ASD as a remarkably heterogeneous constellation of conditions that covary with other disabilities and disorders (e.g., intellectual disability, epilepsy, ADHD, anxiety disorders) and various medical problems. Recent discoveries of underlying genomic factors have shown great complexity and implicate various networks of causal factors. Biological models highlight the likely involvement, at least for a subgroup of patients, of processes associated with synaptic integrity and plasticity. New experimental therapeutics hold promise for the treatment of core symptoms and have the potential to alter developmental trajectories. Treatments in animal models carrying single gene mutations for disorders associated with ASD are particularly promising, ${ }^{84,88,89}$ and most are now in clinical trials. Future research should focus on how we can better match interventions to child and family characteristics through personalized medicine over the lifetime of the patient.

\section{References}

1. Prevalence of autism spectrum disorders - Autism and Developmental Disabilities Monitoring Network, 14 sites, United States, 2008. MMWR Surveill Summ 2012;61:1-19.
2. Elsabbagh M, Divan G, Koh YJ, et al. Global prevalence of autism and other pervasive developmental disorders. Autism Res 2012;5:160-79.

3. Zwaigenbaum L, Bryson SE, Szatmari P, et al. Sex differences in children with autism spectrum disorder identified within a high-risk infant cohort. J Autism Dev Disord 2012;42:2585-96.

4. Ozonoff S, Young GS, Carter A, et al. Recurrence risk for autism spectrum disorders: a baby siblings research consortium study. Pediatrics 2011;128:e488-95.

5. Devlin B, Scherer SW. Genetic architecture in autism spectrum disorder. Curr Opin Genet Dev 2012;22:229-37.

6. Jiang YH, Yuen RK, Jin X, et al. Detection of clinically relevant genetic variants in autism spectrum disorder by whole-genome sequencing. Am J Hum Genet 2013;93:249-63.

7. Pinto D, Pagnamenta AT, Klei L, et al. Functional impact of global rare copy number variation in autism spectrum disorders. Nature 2010;466:368-72.

8. Scherer SW, Dawson G. Risk factors for autism: translating genomic discoveries into diagnostics. Hum Genet 2011;130:123-48.

9. Carter MT, Scherer SW. Autism spectrum disorder in the genetics clinic: a review. Clin Genet 2013;83:399-407.

10. Buxbaum JD, Daly MJ, Devlin B, et al.; The Autism Sequencing Consortium. Large-scale, high-throughput sequencing in autism spectrum disorders. Neuron 2012;76:1052-6.

11. Duncan AM, Chodirker B. Use of array genomic hybridization technology for constitutional genetic diagnosis in Canada. Paediatr Child Health 2011;16:211-2.

12. Miller DT, Adam MP, Aradhya S, et al. Consensus statement: chromosomal microarray is a first-tier clinical diagnostic test for individuals with developmental disabilities or congenital anomalies. Am J Hum Genet 2010;86:749-64.

13. Newschaffer CJ, Croen LA, Fallin MD, et al. Infant siblings and the investigation of autism risk factors. J Neurodev Disord 2012; 4:7.

14. Offit P. Autism's false prophets: bad science, risky medicine, and the search for a cure. 1st ed. New York (NY): Columbia University Press; 2008

15. Fombonne E, Zakarian R, Bennett A, et al. Pervasive developmental disorders in Montreal, Quebec, Canada: prevalence and links with immunizations. Pediatrics 2006;118:e139-50.

16. Hallmayer J, Cleveland S, Torres A, et al. Genetic heritability and shared environmental factors among twin pairs with autism. Arch Gen Psychiatry 2011;68:1095-102.

17. Levy SE, Mandell DS, Schultz RT. Autism. Lancet 2009;374: 1627-38.

18. Zwaigenbaum L. Screening, risk and early identification of autism spectrum disorders. In: Amaral D DG, Geschwind DH, editors. Autism spectrum disorders. Oxford (UK): Oxford University Press; 2009.

19. Johnson CP, Myers SM. Identification and evaluation of children with autism spectrum disorders. Pediatrics 2007;120:1183-215.

20. Gillberg C, Coleman M. Autism and medical disorders: a review of the literature. Dev Med Child Neurol 1996;38:191-202.

21. Kielinen M, Rantala H, Timonen E, et al. Associated medical disorders and disabilities in children with autistic disorder: a population-based study. Autism 2004;8:49-60.

22. Lintas C, Persico AM. Autistic phenotypes and genetic testing: state-of-the-art for the clinical geneticist. J Med Genet 2009; $46: 1-8$.

23. Miles JH, Takahashi TN, Bagby S, et al. Essential versus complex autism: definition of fundamental prognostic subtypes. Am J Med Genet A 2005;135:171-80.

24. Boddaert N, Zilbovicius M, Philipe A, et al. MRI findings in 77 children with non-syndromic autistic disorder. PLOS ONE 2009; 4:e4415.

25. Zecavati N, Spence SJ. Neurometabolic disorders and dysfunction in autism spectrum disorders. Curr Neurol Neurosci Rep 2009; 9:129-36.

26. Buie T, Campbell DB, Fuchs GJ III, et al. Evaluation, diagnosis, and treatment of gastrointestinal disorders in individuals with ASDs: a consensus report. Pediatrics 2010;125(Suppl 1):S1-18.

27. Spence SJ, Schneider MT. The role of epilepsy and epileptiform EEGs in autism spectrum disorders. Pediatr Res 2009;65:599-606.

28. Mahoney WJ, Szatmari P, MacLean JE, et al. Reliability and accuracy of differentiating pervasive developmental disorder subtypes. J Am Acad Child Adolesc Psychiatry 1998;37:278-85.

29. American Psychiatric Association. Diagnostic and Statistical Manual of Mental Disorders. 5th ed. Arlington (VA): 2013.

30. DSM-5 proposed criteria for autism spectrum disorder designed to provide more accurate diagnosis and treatment [press release]. Arlington (VA): American Psychiatric Association; 2012 Mar. 27. Available: www.dsm5.org/Documents/12-03\%20Autism $\% 20$ Spectrum\%20Disorders\%20-\%20DSM5.pdf (accessed 2013 Dec. 9) 
31. Huerta M, Bishop SL, Duncan A, et al. Application of DSM-5 criteria for autism spectrum disorder to three samples of children with DSM-IV diagnoses of pervasive developmental disorders. Am J Psychiatry 2012;169:1056-64.

32. Lord C, Rutter M, DiLavore P, et al. Autism diagnostic observation schedule (ADOS) manual. Los Angeles (CA): Western Psychological Services; 2003

33. Gotham K, Risi S, Dawson G, et al. A replication of the autism diagnostic observation schedule (ADOS) revised algorithms. $J$ Am Acad Child Adolesc Psychiatry 2008;47:642-51.

34. Schopler E, Reichler RJ, DeVellis RF, et al. Toward objective classification of childhood autism: childhood autism rating scale (CARS). J Autism Dev Disord 1980;10:91-103.

35. Chlebowski C, Green JA, Barton ML, et al. Using the childhood autism rating scale to diagnose autism spectrum disorders. $J$ Autism Dev Disord 2010;40:787-99.

36. Lord C, Rutter M, Le Couteur A. Autism diagnostic interviewrevised: a revised version of a diagnostic interview for caregivers of individuals with possible pervasive developmental disorders. J Autism Dev Disord 1994;24:659-85.

37. Dawson G, Rogers S, Munson J, et al. Randomized, controlled trial of an intervention for toddlers with autism: the Early Start Denver Model. Pediatrics 2010;125:e17-23.

38. Smith IM, Koegel RL, Koegel LK, et al. Effectiveness of a novel community-based early intervention model for children with autistic spectrum disorder. Am J Intellect Dev Disabil 2010;115 504-23.

39. Peters-Scheffer N, Didden R, Korzilius H, et al. Cost comparison of early intensive behavioral intervention and treatment as usual for children with autism spectrum disorder in The Netherlands. Res Dev Disabil 2012;33:1763-72.

40. Zwaigenbaum L, Bryson S, Lord C, et al. Clinical assessment and management of toddlers with suspected autism spectrum disorder: insights from studies of high-risk infants. Pediatrics 2009;123:1383-91.

41. Zwaigenbaum L, Bryson S, Garon N. Early identification of autism spectrum disorders. Behav Brain Res 2013;251:133-46.

42. Dahinten S, Ford L. Validation of the Nipissing District developmental screen for use with children and toddlers - working paper. Vancouver (BC): University of British Columbia; 2004; Available: www.effectivepractice.org/site/ywd_effectivepractice /assets/pdf/2c_British_Columbia_Validation_Study.pdf (accessed 2013 Dec. 9).

43. Williams R, Clinton J, Biscaro A. Ontario and the enhanced 18month well-baby visit: trying new approaches. Paediatr Child Health 2008;13:850-6.

44. Pandey J, Verbalis A, Robins DL, et al. Screening for autism in older and younger toddlers with the modified checklist for autism in toddlers. Autism 2008;12:513-35

45. Wetherby AM, Brosnan-Maddox S, Peace V, et al. Validation of the infant-toddler checklist as a broadband screener for autism spectrum disorders from 9 to 24 months of age. Autism 2008;12: 487-511.

46. Wetherby AM, Goldstein H, Cleary J, et al. Early identification of children with communication disorders: concurrent and predictive validity of the CSBS developmental profile. Infants Young Child 2003;16:161-74.

47. Chlebowski C, Robins DL, Barton ML, et al. Large-scale use of the modified checklist for autism in low-risk toddlers. Pediatric 2013;131:e1121-7.

48. Eaves LC, Wingert H, Ho HH. Screening for autism: agreement with diagnosis. Autism 2006;10:229-42.

49. Kleinman JM, Robins DL, Ventola PE, et al. The modified checklist for autism in toddlers: a follow-up study investigating the early detection of autism spectrum disorders. J Autism Dev Disord 2008;38:827-39.

50. Nygren G, Sandberg E, Gillstedt F, et al. A new screening programme for autism in a general population of Swedish toddlers. Res Dev Disabil 2012;33:1200-10.

51. Robins DL, Fein D, Barton ML, et al. The modified checklist for autism in toddlers: an initial study investigating the early detection of autism and pervasive developmental disorders. J Autism Dev Disord 2001;31:131-44.

52. Snow AV, Lecavalier L. Sensitivity and specificity of the modified checklist for autism in toddlers and the social communication questionnaire in preschoolers suspected of having pervasive developmental disorders. Autism 2008;12:627-44.

53. Pierce K, Carter C, Weinfeld M, et al. Detecting, studying, and treating autism early: the one-year well-baby check-up approach. J Pediatr. 2011;159:458-65.

54. Corsello C, Hus V, Pickles A, et al. Between a ROC and a hard place: decision making and making decisions about using the SCQ. J Child Psychol Psychiatry 2007;48:932-40.

55. Oosterling I, Rommelse N, de Jonge M, et al. How useful is the
Social Communication Questionnaire in toddlers at risk of autism spectrum disorder? J Child Psychol Psychiatry 2010;51: 1260-8

56. Simonoff E, Pickles A, Charman T, et al. Psychiatric disorders in children with autism spectrum disorders: prevalence, comorbidity, and associated factors in a population-derived sample. J Am Acad Child Adolesc Psychiatry 2008;47:921-9.

57. Mazzone L, Ruta L, Reale L. Psychiatric comorbidities in asperger syndrome and high functioning autism: diagnostic challenges. Ann Gen Psychiatry 2012;11:16.

58. National standards report: the National Standards Project addressing the need for evidence-based practice guidelines for autism spectrum disorders. Randolph (MA): National Autism Center; 2009.

59. Cooper JO, Heron TE, Heward WL. Applied behavior analysis. Columbus (OH): Merrill Publishing; 1987.

60. Reichow B. Overview of meta-analyses on early intensive behavioral intervention for young children with autism spectrum disorders. J Autism Dev Disord 2012;42:512-20.

61. Peters-Scheffer N, Didden R, Korzilius H, et al. A meta-analytic study on the effectiveness of comprehensive ABA-based early intervention programs for children with autism spectrum disorders. Res Autism Spectr Disord 2011;5:60-9.

62. Virués-Ortega J. Applied behavior analytic intervention for autism in early childhood: meta-analysis, meta-regression and doseresponse meta-analysis of multiple outcomes. Clin Psychol Rev 2010;30:387-99.

63. Reichow B, Barton EE, Boyd BA, et al. Early intensive behavioral intervention (EIBI) for young children with autism spectrum disorders (ASD). Cochrane Database Syst Rev 2012;(10): CD009260.

64. Makrygianni MK, Reed P. A meta-analytic review of the effectiveness of behavioural early intervention programs for children with autistic spectrum disorders. Res Autism Spectr Disord 2010;4:577-93.

65. Perry A, Cummings A, Geier JD, et al. Predictors of outcome for children receiving intensive behavioral intervention in a large, community-based program. Res Autism Spectr Disord 2011;5: 592-603.

66. Koegel RL, Koegel L.K, O'Neill R. Generalization in the treatment of autism. In: Spradlin LVMJE, editor. Generalization strategies in the treatment of communication disorders. Toronto (ON): Decker; 1989:116-31.

67. Carter AS, Messinger DS, Stone WL, et al. A randomized controlled trial of Hanen's "More Than Words" in toddlers with early autism symptoms. J Child Psychol Psychiatry 2011;52:741-52.

68. Perry A, Cummings A, Dunn Geier J, et al. Effectiveness of intensive behavioral intervention in a large, community-based program. Res Autism Spectr Disord 2008;2:621-42.

69. McCracken JT, McGough J, Shah B, et al. Risperidone in children with autism and serious behavioral problems. $N$ Engl J Med 2002;347:314-21.

70. King BH, Hollander E, Sikich L, et al. Lack of efficacy of citalopram in children with autism spectrum disorders and high levels of repetitive behavior: citalopram ineffective in children with autism. Arch Gen Psychiatry 2009;66:583-90.

71. Research Units on Pediatric Psychopharmacology Autism Network. Risperidone treatment of autistic disorder: longer-term benefits and blinded discontinuation after 6 months. Am J Psychiatry 2005; 162:1361-9.

72. Jesner OS, Aref-Adib M, Coren E. Risperidone for autism spectrum disorder. Cochrane Database Syst Rev 2007;(1)CD005040.

73. Ching H, Pringsheim T. Aripiprazole for autism spectrum disorders (ASD). Cochrane Database Syst Rev 2012;(5):CD009043.

74. Malow BA, Byars K, Johnson K, et al. A practice pathway for the identification, evaluation, and management of insomnia in children and adolescents with autism spectrum disorders. Pediatrics 2012;130(Suppl 2):S106-24.

75. Owen R, Sikich L, Marcus RN, et al. Aripiprazole in the treatment of irritability in children and adolescents with autistic disorder. Pediatrics 2009; 124:1533-40.

76. Posey DJ, Aman MG, McCracken JT, et al. Positive effects of methylphenidate on inattention and hyperactivity in pervasive developmental disorders: an analysis of secondary measures. Biol Psychiatry 2007;61:538-44.

77. Harfterkamp M, van de Loo-Neus G, Minderaa RB, et al. A randomized double-blind study of atomoxetine versus placebo for attention-deficit/hyperactivity disorder symptoms in children with autism spectrum disorder. J Am Acad Child Adolesc Psychiatry 2012;51:733-41.

78. Arnold LE, Aman MG, Cook AM, et al. Atomoxetine for hyperactivity in autism spectrum disorders: placebo-controlled crossover pilot trial. J Am Acad Child Adolesc Psychiatry 2006; 45:1196-205. 
79. Handen BL, Sahl R, Hardan AY. Guanfacine in children with autism and/or intellectual disabilities. J Dev Behav Pediatr 2008; 29:303-8.

80. Rossignol DA, Frye RE. Melatonin in autism spectrum disorders: a systematic review and meta-analysis. Dev Med Child Neurol 2011;53:783-92.

81. McDougle CJ, Scahill L, Aman MG, et al. Risperidone for the core symptom domains of autism: results from the study by the autism network of the research units on pediatric psychopharmacology. Am J Psychiatry 2005;162:1142-8.

82. Reed HE, McGrew SG, Artibee K, et al. Parent-based sleep education workshops in autism. J Child Neurol 2009;24:936-45.

83. Vriend JL, Corkum PV, Moon EC, et al. Behavioral interventions for sleep problems in children with autism spectrum disorders: current findings and future directions. J Pediatr Psychol 2011;36:1017-29.

84. Anagnostou E, Hansen R. Medical treatment overview: traditional and novel psycho-pharmacological and complementary and alternative medications. Curr Opin Pediatr 2011;23:621-7.

85. Billstedt E, Gillberg IC, Gillberg C. Autism after adolescence: population-based 13- to 22-year follow-up study of 120 individuals with autism diagnosed in childhood. [published in erratum in J Autism Dev Disord 2007;37:1822]. J Autism Dev Disord 2005; 35:351-60.

86. Howlin P. Outcomes in autism spectrum disorders. In: Volkmar FR, Paul R, Klin A, et al., editors. Handbook of autism and pervasive developmental disorders. 3rd ed. Hoboken (NJ): Wiley; 2005: 201-22.

87. Stoddart K, Burke L, Muskat B, et al. Diversity in Ontario's youth and adults with autism spectrum disorders: complex needs in unprepared systems. Toronto (ON): The Redpath Centre; 2013.

88. Ehninger D, Silva AJ. Genetics and neuropsychiatric disorders: treatment during adulthood. Nat Med 2009;15:849-50.

89. Novarino G, El-Fishawy P, Kayserili H, et al. Mutations in BCKD-kinase lead to a potentially treatable form of autism with epilepsy. Science 2012;338:394-7.

Competing interests: Janet Buchanan is an independent contractor employed by The Centre for Applied Genomics at the Hospital for Sick Children. Evdokia Anagnostou has received consultant's fees from Seaside Therapeutics and Novartis, grants from Sanofi Canada and royalties from the American Psychiatric Association for a clinical manual of autism treatment. Lonnie Zwaigenbaum holds funding from SynapDX for clinical investigation of RNA expression profiles to aid in the early diagnosis of autism spectrum disorder. Peter Szatmari receives royalties from Guildford Press for a book about autism. Eric Fombonne has received consultant's fees from Forest Lab and speaker fees from the University of California, Los Angeles. Stephen Scherer holds an Endowed
Chair (from GlaxoSmithKline and the Canadian Institutes of Health Research) and is an advisor to Population Genomics and founding scientist of YouNique Genomics. No other competing interests declared.

Affiliations: Holland Bloorview Kids Rehabilitation Centre (Roberts), Bloorview Research Institute (Anagnostou, Brian), Molecular Genetics (Scherer), McLaughlin Centre, University of Toronto, Toronto, Ont.; Department of Pediatrics (Zwaigenbaum), University of Alberta, Edmonton, Alta.; Department of Psychiatry (Szatmari), Austism Research Unit (Drmic, Roberts), The Centre for Applied Genomics (Buchanan, Scherer), The Hospital for Sick Children, Toronto, Ont.; Department of Child and Adolescent Psychiatry (Szatmari), Centre for Addiction and Mental Health, Toronto, Ont; Department of Psychiatry (Fombonne), Montreal Children's Hospital, Montréal, Que.; McGill University (Fombonne), Montréal, Que.; Disciplines of Genetics and Medicine (Fernandez), Memorial University of Newfoundland, St. John's, NL; Psychiatry and Behavioural Neurosciences (Woodbury-Smith), Offord Centre for Child Studies (Drmic), McMaster University, Hamilton, Ont.; Pediatrics and Psychology (Bryson, Smith), Dalhousie University, Halifax, NS; Autism Research Centre (Bryson, Smith), IWK Health Centre, Halifax, NS.

Contributors: All of the authors contributed to the writing and revising of the manuscript. All of the authors approved the final version submitted for publication.

Acknowledgements: The authors thank Dr. Melissa Carter for helpful commentary.

Janet Buchanan's work on this article was supported by funds from the University of Toronto McLaughlin Centre. Lonnie Zwaigenbaum holds the Stollery Children's Hospital Foundation Chair in Autism. Peter Szatmari holds the Jamie and Patsy Anderson Chair in Child and Youth Mental Health at the Hospital for Sick Children, Centre for Addiction and Mental Health and University of Toronto. Eric Fombonne holds the Monique H. Bourgeois Chair for Research on Pervasive Developmental Disorders and a Canada Research Chair in Child Psychiatry Tier I. Susan Bryson holds the Joan and Jack Craig Chair in Autism Research at Dalhousie University. Stephen Scherer holds the GlaxoSmithKline Canadian Institutes of Health Research Pathfinder Chair in Genome Sciences at the University of Toronto and the Hospital for Sick Children. 